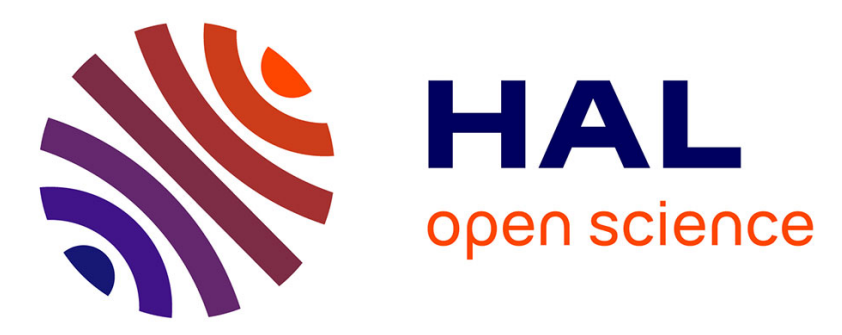

\title{
Relation between redox potential and oxygen levels in activated-sludge reactors
}

\author{
Alain Heduit, Daniel R. Thevenot
}

\section{To cite this version:}

Alain Heduit, Daniel R. Thevenot. Relation between redox potential and oxygen levels in activatedsludge reactors. Water Science and Technology, 1989, 21, pp.947 - 956. hal-01084520

\section{HAL Id: hal-01084520 \\ https://hal-enpc.archives-ouvertes.fr/hal-01084520}

Submitted on 19 Nov 2014

HAL is a multi-disciplinary open access archive for the deposit and dissemination of scientific research documents, whether they are published or not. The documents may come from teaching and research institutions in France or abroad, or from public or private research centers.
L'archive ouverte pluridisciplinaire HAL, est destinée au dépôt et à la diffusion de documents scientifiques de niveau recherche, publiés ou non, émanant des établissements d'enseignement et de recherche français ou étrangers, des laboratoires publics ou privés.

\section{(c)(1)}

Distributed under a Creative Commons Attribution| 4.0 International License 


\title{
RELATION BETWEEN REDOX POTENTIAL AND OXYGEN LEVELS IN ACTIVATED-SLUDGE REACTORS
}

\author{
Alain Heduit ${ }^{*}$ and Daniel R. Thevenot ${ }^{* *}$ \\ "Centre National du Machinisme Agricole, du génie Rural, des Eaux et \\ des Forêts (CEMAGREF) Unité Qualité des Eaux Pêche et Pisciculture, \\ 14 avenue de Saint-Mande, 75012 Paris, France \\ "Université Paris-Val de Marne (U.P.V.M.), U.F.R. de Sciences et de \\ Technologie, Laboratoire de Bioélectrochimie et Analyse du Milieu, \\ Avenue du Général de Gaulle, F.94010 Creteil, France
}

\section{ABSTRACT}

The importance of dissolved oxygen level in determining the platinum electrode potential in activated sludge has been clearly demonstrated by current-potential curves plotted at different oxygen concentrations.

Tests have been carried out, in the laboratory and in full scale treatment plants, to define the relationship between the platinum electrode potential at equilibrium (Eh) and the dissolved oxyen $\left[\mathrm{O}_{2}\right]$ concentration in the activated sludge. rhese two paramecers obey a law of the form Eh $=a+b \log \left[\mathrm{O}_{2}\right]$. The measured values of coefficents $a$ and $b$ differ widely to those found from the oxygen reduction reaction in water $(0=0.8 \quad \mathrm{~V}$ at pH 7 and $b=15$ mV per decede).

Factors $a$ and $b$ mainly depend on the sludge loading, the aeration conditions and the siudge concentration. Using non-polished stationary platinum ring electrodes, the following values of $Q$ were obtained (at pH between 7 and 7.6 ) : * 410 mV/NHE for sludge aerated for several hours without feeding, +265 mV/NHE for over-aerated/low-loaded sludge $(\mathrm{Cm}=0.2 \mathrm{~kg}$ BOD.kg MLVSS-1, day-") and $=180 \mathrm{mV} / \mathrm{NHE}$ for high-loaded activated siudge in plug-flow system $\left(\mathrm{Cm}=1 \mathrm{~kg} \mathrm{BOD} \cdot \mathrm{kg}\right.$ MLVSS $^{-1}$. day $\left.{ }^{-1}\right)$. Factor $D$ would seem to lie between 55 and 65 mV when the sludge is continuously aerated without feeding. At low loads with excess aeration, it lies between 70 and 90 mV. Wher the medium is slightly septic at low dissolved oxygen concentrations (insufficient daily aeration time, high sludge concentration or aerators shut down for too long periods). factor $b$ increases and can reach $200 \mathrm{mV}$. In the same way, at high loads, factor b can become $150 \mathrm{mV}$.

These results demonstrate the importance of dissolved oxygen concentration in the mechanisms which determine the metal electrode potentials in activated sludge. They also illustrate the role that other electroactive species play in the process. The type and concentration of these species depend on parameters such as the sludge loading, the overall oxygen supply, the aeration sequence and the sludge concentration.

KEYwORDs : activated sludge, redox potential, oxygen, wastewater treatient plant, instrumentation, control.

\section{INTRODUCTION}

Various authors have recently demonstrated the practical importance of zero-current potential measurements in activated sludge in controlling nitrification and denitrification processes (Tanaka et al.. 1982, Fujil, 1983, Charpentien et al., 1987). Several patents have been taken out as a result of these studies (H1tachi Ltd, Kankyo Engineering Co Ltd, Meidensha Electric Mrg Co Ltd, Mitgubtohi Heavy Industriea, Nippon Steel Corp.) 
The metal electrode potential in aerated sludge probably originates from several sources : redox species in the interstitial water (from the wastewater or produced by the bacterial metabolism), redox enzymes (for example, flavins), $\mathrm{pH}$, dissolved oxygen, etc. The easiest parameters to monitor in treatment plants are the $\mathrm{pH}$ and the dissolved oxygen content. Variations in the $\mathrm{pH}$ of activated sludge in extended aeration rarely exceed a few tenths of a unit. However, it would seem advisahle to measure pH in conjunction with the potential measurements to attempt to determine the reaction mechanisms occurring at watal interfaces.

In general terms, dissolved oxygen is reduced in line with the equation :

$$
\mathrm{O}_{2}+4 \mathrm{H}^{+}+4 \mathrm{e}^{-} \rightleftarrows 2 \mathrm{H}_{2} \mathrm{O}
$$

If the partial oxygen pressure is expressed in atmospheres, its normal potential at $20^{\circ} \mathrm{C}$ is $1.228 \mathrm{~V} / \mathrm{NHE}$ (Milazzo, 1969). If the dissolved oxygen content is expressed by weight, the normal potential becomes $1.251 \mathrm{~V} / \mathrm{NHE}$ and the apparent normal potential at $\mathrm{pH} 7$ is then $0.846 \mathrm{~V} / \mathrm{NHE}$.

The Nernst equation can then be written :

$$
E=1.251-0.058 \mathrm{pH}+0.015 \log \left[0_{2}\right]
$$

Where :

E : the oxidation reduction potential/NHE (Volts)

$\log$ : the logarithm to a base of 10

$\left[\mathrm{O}_{2}\right]$ : the dissolved oxygen concentration (mg. $1^{-1}$ ).

Our earlier work on pilot plants demonstrated that, when they are subjected to cyclic feed and aeration conditions, the redox potential of polished platinum electrodes reached at the end of the aeration periods (Eh*) is related to the nitrification efficiency (Hedurt et al., 1987.). The (Eh*) potential for one of the two pilot plants was found to be closely correlated with the dissolved oxygen concentration

$E h^{*}=0.398+0.080 \log \left[\mathrm{O}_{2}\right] \quad n=6 \quad r=0.92$.

This equation is similar to (1):

$$
E=a+b \log \left[\mathrm{O}_{2}\right]
$$

but parameters $a$ and $b$ differ significantly from thermodynamic values.

Regardless of variations due to the dissolved oxygen concentration, the electrode potential in activated sludge seems to be heavily affected by other electroactive species : according to Nussberger, quoted by Burbank (1982) and Bejaoui (1977), the potential reached by a platinum electrode in sludge sampled from a plant and then aerated without feeding is higher if the plant is underloaded or over-aerated.

Finaliy, it must be remembered that the metal electrode potential at equilibrium conditions in activated sludge is not an equilibrium thermodynamic potential since low-concentration electroactive species are probably involved. This means that the surface condition of the electrode (and, therefore, the preparatory treatment applied to it) has a considerable effect on its response (Coquery, 1986 ; Hedult et al., 1987b). However, it is possible to obtain repeatable measurements (to within $\pm 10 \mathrm{mV}$ ) at stabilized conditions by using electrodes in the same material, of the same shape and prepared in the same way.

MATERIAL AND METHODS

\section{ELECTROCHEMICAL EQUIPMENT}

In the laboratory, the current-potential curves were plotted at low speed (1.25 mV.s using a Tacussel PRG 3 assembly conprising :

- a potential controlling unit (FF 20-2X)

an adaptor unit (UAP 3 .

- a voltage recorder (EPL 2) fitted with a control system. 
The plots were taken from fixed platinum electrodes dipped into stirred samples. The indicating electrodes, used both for laboratory and on-site tests, consist of a platinum ring $\left(S=0.5 \mathrm{~cm}^{2}\right.$ ) (Ingold $\mathrm{Pt} 805$ ). The reference electrodes (Xerolyt) contain a solid electrolyte. On the site, they are placed in PVC tubes fitted with o-rings which allow them to be submerged to approximately $80 \mathrm{~cm}$. The indicating electrodes and the common reference electrode used with them are connected to high input-impedance millivoltmeters (Knick 646), themselves connected to graphic recorders (Goerz Servogor 460.06) fitted with variable sensitivity units. Ponselle $\mathrm{O}_{2} \mathrm{P}$ oxygen-meters (amperometric gensors) are used to measure the oxygen concentrations. Portable Schott CG $817 \mathrm{pH}$ meters are used.

\section{THE LABORATORY TEST CELL}

This is a rectangular 2 liter transparent PVC cell capable of accomodating 10 electrodes. It is generally placed on a magnetic agitator and the liquid is stirred by a teflon rod. The dissolved oxygen concentration in the medium is varied by an aquarium compressor or a bottle of nitrogen.

\section{WASTEWATER TREATMENT PLANTS}

Tests were carried out on 3 different plants.

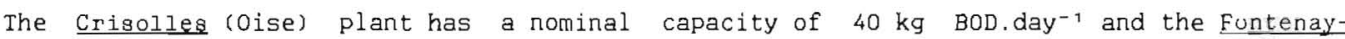
Tresigny (Seine et Marne) plant $300 \mathrm{~kg} \mathrm{BOD.day}{ }^{-1}$. Both operate on activated sludge/extended aeration/complete mixing mode. They are equjpped with intermittently-operating surface aerators : At Crisolles, it is a $7.5 \mathrm{~kW}$ SEM Low-speed vertical-axis aerator on a cylindrical aeration tank $(V=140 \mathrm{~m})$ and at Fontenay-Tresigny, two 15 kw France Assainisement/Rollox low-speed horizontal-axis aerators on an annular basin $\left(V=1040 \mathrm{~m}^{3}\right)$.

The $\underline{\mathrm{C} g l o m b e s}$ (Hauts de Seine) aeration basin tested $\left(\mathrm{V}=800 \mathrm{~m}^{\mathbf{3}}\right.$ ) operates at high loads ( 1 $\mathrm{kg}$ BOD. (m-3 $\mathrm{may}^{-1}$ ) and on plug flow. It is fitted with a fine air bubble blowing system, controlled by an oxygen-meter, and receives decanted wastewater.

The flows were measured using an Isco bubble flow-meter (with record and printer), coupled to the plant weir. The inlet and outlet water samples are collected by APAE $241 \mathrm{~F}$ and ISCO automatic samplers respectively. Table 1 summarizes the main operating parameters of these plants during the experimental period.

Table 1 : process operating parameters for the 3 plants tested

\begin{tabular}{|c|c|c|c|c|c|c|c|c|c|c|c|}
\hline \multirow[t]{2}{*}{$\begin{array}{c}\text { Treatment } \\
\text { Plant }\end{array}$} & \multirow[t]{2}{*}{$\mathrm{C}_{m}{ }^{\circ}$} & \multirow[t]{2}{*}{$\mathrm{C}_{\checkmark}{ }^{\circ} \mathrm{O}$} & \multirow{2}{*}{$\begin{array}{l}\text { MLSS* } \\
\% \\
\text { MLVSS* * }\end{array}$} & \multirow[t]{2}{*}{ HRT $X X X$} & \multirow{2}{*}{$\begin{array}{l}\text { Daily } \\
\text { aeration } \\
\text { time }\end{array}$} & \multirow[t]{2}{*}{$\mathrm{pH}$} & \multirow[t]{2}{*}{$\left(\stackrel{\theta}{\left({ }^{\circ}\right.}\right)$} & \multicolumn{4}{|c|}{$\begin{array}{c}\text { Results of effluent analysis } \\
\text { (mg. } \mathrm{l}^{-1} \text { ) }\end{array}$} \\
\hline & & & & & & & & DCO & $\mathrm{N}-\mathrm{NH}_{4}+$ & $\mathrm{N}-\mathrm{NO}_{2}-$ & $\mathrm{N}-\mathrm{NO}_{3}$ \\
\hline $\begin{array}{l}\text { Crisolles } \\
\text { Aug.17-20(87) }\end{array}$ & 0.2 & 0.3 & $\begin{array}{l}2.6 \\
60 \%\end{array}$ & 26 & $10 \mathrm{~h}$ & $\begin{array}{l}7.5- \\
7.6\end{array}$ & $21^{\circ}$ & 35 & 3 & 0.4 & 7 \\
\hline $\begin{aligned} \text { Fontenay- } & \\
& \text { Tresigny } \\
\text { Aug. } & 6-11 \\
& (1987)\end{aligned}$ & 0.04 & 0.2 & $\begin{array}{l}8.5 \\
65 \%\end{array}$ & 35 & $10 \mathrm{~h} 45$ & $\begin{array}{l}7.2- \\
7.4\end{array}$ & $18^{\circ}$ & 20 & 0.7 & 0.02 & 0.2 \\
\hline $\begin{array}{c}\text { Aug. } 31-\text { Sep. } 3 \\
(1987)\end{array}$ & 0.04 & 0.2 & $\begin{array}{l}8.1 \\
67 \%\end{array}$ & 35 & 8 h 45 & $\begin{array}{l}7- \\
7.2\end{array}$ & $18^{\circ}$ & 50 & 4.5 & 0.04 & 0.3 \\
\hline $\begin{array}{l}\text { Colombes } \\
\text { Aug. 25-27(87) }\end{array}$ & 1.2 & 1.05 & $\begin{array}{l}1.3 \\
67 \%\end{array}$ & I h 20 & continu & $\begin{array}{l}7- \\
7.5^{-}\end{array}$ & $18^{\circ}$ & 40 & 5 & 0.3 & 2 \\
\hline
\end{tabular}

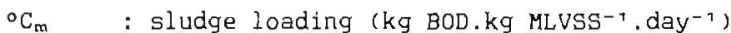

${ }^{\circ} \mathrm{C}_{\mathrm{V}} \quad$ : BOD loading ( $\mathrm{kg} \mathrm{BOD} \cdot \mathrm{m}^{-3} \cdot \mathrm{day}^{-1}$ )

* MLSS : mixed liquor suspended solids (g. ${ }^{-1}$ )

\% MLVSS : percentage of mixed liquor volatile suspended solids in the MLSS $(\%)$

HRTxxx : Hydraulic Retention Time (h). 


\section{ELECTROCHEMICAL MEASUREMENT}

In the presence of a reversible equilibrium between species such as $\left[\mathrm{Fe}\left(\mathrm{CN}_{6}\right)\right]^{3-} /\left[\mathrm{Fe}\left(\mathrm{CN}_{0}\right)\right]^{4-}$ which rapidly exchange electrons with the electrode and if their concentration is sufficiently high, an inert electrode reaches a reproducible equilibrium potential ( $\left.E_{1-0}\right)$ defined by the Nernst law. In these conditions, the electrode is subjected to two oppositepolarity currents ( $\mathrm{JO}_{\text {a }}$ and $\mathrm{JO}_{c}$ ) such that the resultant current is zero (figure 1 ).
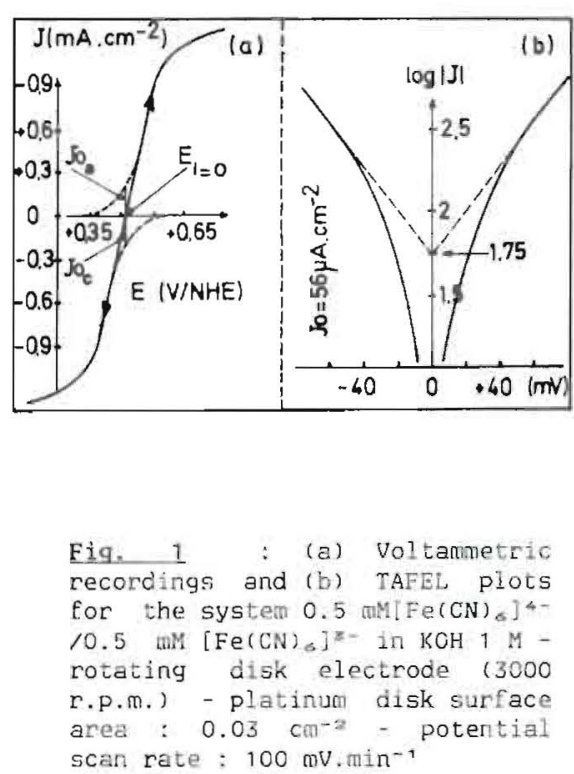

To measure the zero current potential, it is first necessary to determine the difference between the metal electrode equilibrium voltage and the potential of a reference electrode. This is done using a high inputimpedance millivoltmeter.

The equilibrium current density (Jo) is conventionally determined, at pure transfer conditions, by recording current-voltage curves at anodic or cathodic potential scans low speeds (voltammetric measurement) and then plotting curves of the logarithm of the current density ( $\log J)$ against the applied overpotential (n). The exchange current denaity (Jo) at the equilibrium potential is then determined by extrapolating these curves to zero overpotential :

$\log |\mathrm{J}|=\log |\mathrm{J} 0|+\mathrm{k} n$

where :

$\mathrm{J}$ : the current density $=$ (current through the circuit/working electrode area (mA. $\left.\mathrm{cm}^{-2}\right)$

Jo: the exchange current density $\left(\mu \mathrm{A} . \mathrm{cm}^{-2}\right)$

$n:$ the overpotential $=$ applied potential imposed - equilibrium potential (v)

\section{LAGORATORY AND ON-SITE TEST PROCEDURES}

In the laboratory, the electrodes are cleaned and then dipped into the medium approximately one hour before starting measurement. To clean the platinum electrodes, they are simply washed in tap water after degreasing them with acetone. The sludge is always aerated before submergence of the electrodes and the first values measured are always those at the highest value of the variable oxygen concentration $\left[\mathrm{O}_{2}\right]$. In this case, each oxygen concentration and potential equilibrium point is held for at least 10 tiinutes. The preparatory treatment may be repeated during the experiments to check the repeatability of the measurement at a given oxygen concentration.

On the site, several platinum electrodes, the common reference electrode and an $\mathrm{O}_{2}$ sensor are introduced into the aeration tank simultaneously. Flow measurements and water sampling begin at the same time. The hourly samples taken are grouped in proportion to the corresponding flow to form 24 hours composite samples which are then analyzed for COD and amonia, nitrous and nitric nitrogen. The temperature, pH, mixed liquor suspended solids (MLSS) and mixed Iiquor volatile suspended solids (MLVSS) are measured on the sludge each day. The electrodes are cleaned each day and each test period lasts three to six days.

All zero current potential. (Eh) values have been averaged for 2-3 indicating electrodes. 


\section{RESULTS AND DISCUSSTION}

\section{VOLTAMMETRIC MEASUREMENT}

Figure 2 gives the typical current-potential curves obtained from platinum electrodes in activated sludge at three different dissolved oxygen concentrations. The progressive disappearance of the cathodic branch as the dissolved oxygen concentration diminishes shows that this branch probably represents the electrochemical reduction of the dissolved oxygen.

These experiments show how the dissolved oxygen reduction reaction contributesto the establishment of a metal electrode equilibrium potential in activated sludge. Tafel plots obtained for figure 2 experimental conditions give an equilibrium exchange current density around $40 \mathrm{nA}_{\mathrm{Cm}} \mathrm{Cm}^{-2}$ (anodic and cathodic scans).

The following values had already been measured for this type of electrode under steady state conditions (Heduit, 1985) :

. $20 \mathrm{nA} \cdot \mathrm{cm}^{-2}$ in sludge held under anoxic conditions $(E=-0.3 \mathrm{~V} / \mathrm{NHE})$

$50 \mathrm{nA} \cdot \mathrm{cm}^{-2}$ in aerated activated sludge under endogenic uptake rate ( $E=+0.3 \mathrm{~V} / \mathrm{NHE})$ and 24 hours after electrochenical pretreatment of the metal (triangular signals et $2500 \mathrm{~Hz}$ between -1.5 and + $1.5 \mathrm{~V} / \mathrm{SCE}$ for 2.5 minutes).

These very low density values for the exchange current Jo are related to the electrochemical spectes present in the medium (slow systems) and the fact that the metal is not activated. Densities 10 times higher were found immediately after mechanical polishing of the metal. However, this effect disappears within a few hours (Heduit, 1985). This type of treatment cannot be easily automated on a real site and so was not used during the remeinder of the experiments described here.

\section{RELATION BETWEEN ZERO-CURRENT CONCENTRATION}

\subsection{Effect of preliminary aeration of sludge}

\author{
Fiq. 3 : Variation of zero \\ current potential with dissolved \\ oxygen concentication in \\ activated sludge, sampled from \\ the Fontenay-Iresigny plant, : \\ (__) sludge previously aerated \\ for 12 hours without feeding \\ (--) sludge previously held \\ under anoxic conditions for 12 \\ hours without feeding \\ a First experimental period \\ - Second experimental period
}


Figure 3 shows the variations, obtained in the laboratory, of the zero current electrode potential (Eh) plotted against the dissolved oxygen content $\left[\mathrm{O}_{2}\right]$ in activated sludge which was previously either aerated, without feeding, for 12 hours or held under anoxic conditions, without feeding, for the same period. These sludges were sampled from the Fontenay-Tresigny treatment plant during 2 different periods described in Table 1.

The effect of $\mathrm{pH}$ on the results must be mentioned : over-aeration of the sludge immediately prion to the experiment causes an appreciable increase in pH (from 7.2 to epprox 8.5) due to displacement of the $\mathrm{CO}_{2}$. The reverse is also true, i.e. the $\mathrm{pH}$ is reduced by approx 0.5 unit when the dissolved oxygen concentration is reduced during the experiment.

Sulfuric acid and then soda were added to treated water, saturated with dissolved oxygen at $21^{\circ} \mathrm{C}$, to assess the effect of variations in $\mathrm{pH}$ on the Eh potential (see Figure 4 ).

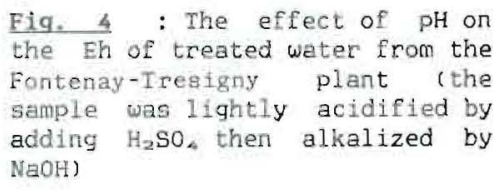

Fig. 4 : The effect of $\mathrm{pH}$ on the Eh of treated water from the sample was lightly acidified by adding $\mathrm{H}_{2} \mathrm{SO}_{4}$, then alkalized by

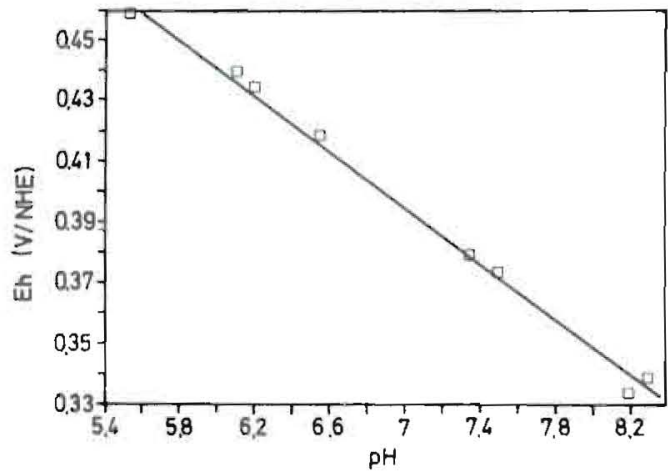

The following relationship has been obtained:

$E h=0.721-0.046 \mathrm{pH}$

$(n=8 ; r=0.99)$

Using this $46 \mathrm{mV}$ variation of Eh per pH unit, figure 3 data were corrected to "standardize" them at $\mathrm{pH}=7$. These corrected values were plotted against log $\left[\mathrm{O}_{2}\right]$ (fiqure 5 ). The linear regressions obtained from these corrected values give :

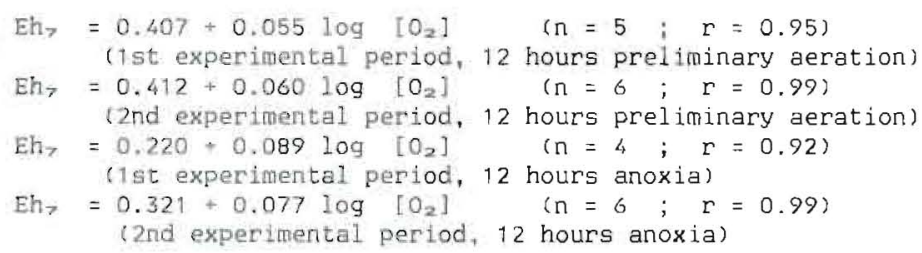

Eh, = electrode potential corrected back to $\mathrm{pH}=7(\mathrm{~V} / \mathrm{NHE})$

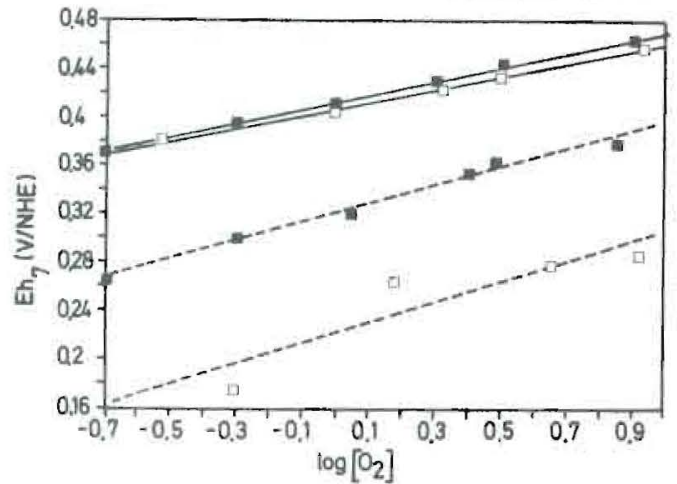

Fig. 5 : Eh potential values from figure 3 corrected back to $\mathrm{pH}=7$ ( $46 \mathrm{mV}$ shift per $\mathrm{pH}$ unit) against the logarithm of the corresponding dissolved oxygen concentration (expressed in $\mathrm{mg}$ $\mathrm{O}_{2} \cdot \mathrm{l}^{-1}$ )

(__ sludge previously aerated for 12 hours without feeding

(--) sludge previously held under anoxic conditions for 12 hours without feeding

a First experimental period

- Second experimental period 
The two continuous lines (sludge previously aerated for 12 hours) are very close to each other. Both dotted lines (sludge held under anoxic conditions for 12 hours) are lower than continuous lines and separated from each other (figure 5). This discrepancy between the dotted lines related to the difference in the length of the aeration period prior to the experiment. If a sufficient aeration period is used, these two dotted lines rise and coincide with the continuous lines. This experience shows that, depending on the sludge aeration conditions, the absolute value of the potential measured varles significantly at a given oxygen concentration.

\subsection{The effect of sewage addition}

Adding $20 \mathrm{ml}$ of wastewater into 2 liters of aerated sludge causes an immediate drop in the sludge potential by 20 to $50 \mathrm{mv}$. The dissolved oxygen concentration drops by a maximum of $1 \mathrm{mg} / \mathrm{l}$ (from 8 to $7 \mathrm{mg} / \mathrm{l}$ ) but the $\mathrm{pH}$ remains constant (figure 6). After several minutes, the potential and oxygen concentrations return to their initial values. Under these conditions, the potential drop seems directly related to wastewater species or to biological products, indeed oxygen level would not modify Eh by more than $3 \mathrm{mv}$ (see figure 3 ).

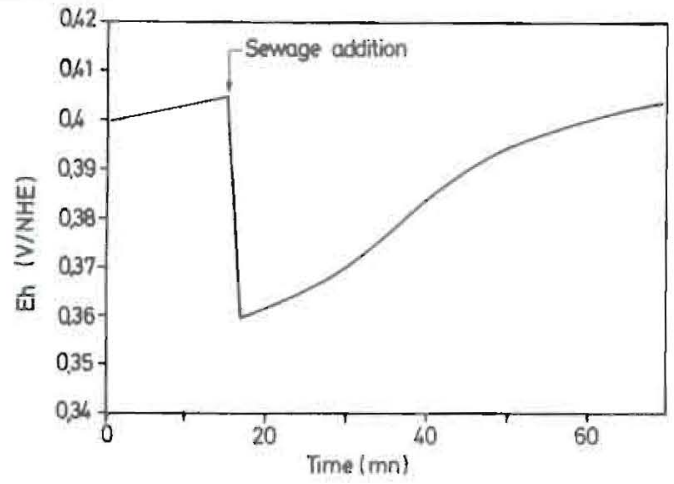

Fig. 6 : The typical effect of adding $20 \mathrm{ml}$ of waste water to 2 liters of activated sludge from the Fontenay-Tresigny plant previously aerated for 12 hours without feeding

2.3 Data collected from real plants

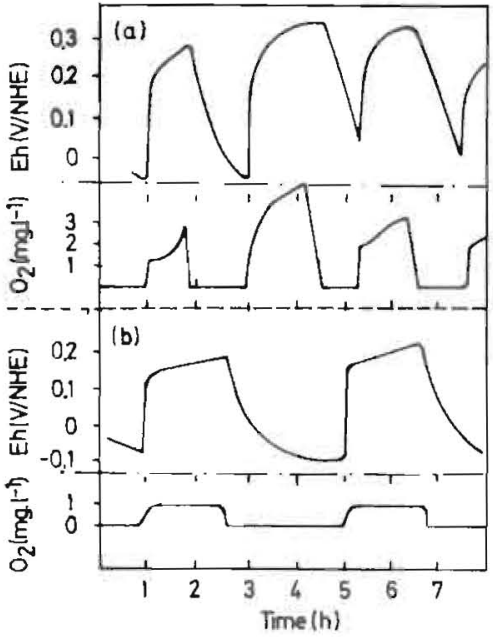

Fiq. 7 : Examples of corresponding changes in Eh potential and dissolved oxygen concentration mittently aerated an intermittently aerated
(Fontenay-Tresigny plant)

a : first experimental period

$b$ : second experimental period
The evolution of Eh and dissolved oxygen curves obtained from wastewater treatment plants fitted with surface aerators present 2 alternative patterns :

Either both the dissolved oxygen concentration and the potential rise instantaneously as the aerator starts and then tend to become asymptotic (figure 7 a) or, when the aeration is started, the oxygen concentration and potential again rise immediately but the oxygen concentration quickly stabilizes at a relatively low value while the potential continues to increase slowly (figure 7 b).

In the first case, the degradation of the substrate (oxidation) quickly depletes the nutritive substance in the medium and thus reduces the oxyyen uptake rate, causing an attendant increase in dissolved oxygen concentration and potential. In the second case, the fact that the oxygen concentration quickly stabilizes at a low value leads to constant high oxygen uptake rate (excessive substrate). As aeration continues, the organic matter is assimilated or oxidized and the potential, therefore, continues to increase. In nelther case are the potentials completely stable. They are not, therefore, truly equilibrium potentials even after aeration for several hours. 
The potentials reached at the end of the aeration periods were plotted against the logarithm of the dissolved oxygen concentration for the Crisolleg treatment plant (figure 8).

The equation of the regression line is :

$E h^{*}=0.264+0.091 \log \left[\mathrm{O}_{2}\right] \quad(\mathrm{pH}=7.5 ; \quad r=0.92 \quad n=37)$

where :

$E h^{*}=$ potential reached at the end of the aeration period (V/NHE)

$\left[0_{2}\right]=$ the dissolved oxygen concentration (mg. $1^{-1}$ )

At a given dissolved oxygen concentration, the potentials measured in situ are considerabiy lower than those obtained in the laboratory when sludge samples are aerated without feeding (see figure 5 ).
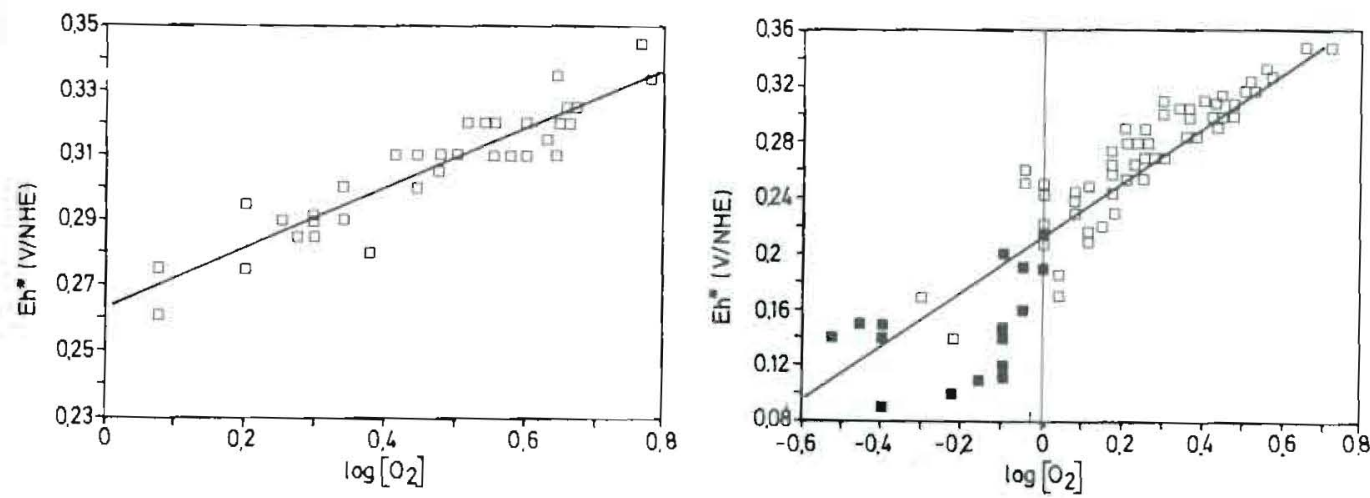

Fiq. 8 : The Crisolles plant : potentials reached in situ at the end of the aeration periods against the logarithm of the dissolved oxygen concentration (expressed in ing $0_{2} .1^{-1}$ )

The potentials achieved at the end of the aeration periods have been plotted against the logarithm of the dissolved oxygen concentrations for the Fontenay-Tresigny treatment plant (figure 9). The equation of the regression line is :

Eh* $=0.213+0.197 \log \left[\mathrm{O}_{2}\right] \quad(\mathrm{pH}=7.2 ; \mathrm{r}=0.90 ; n=96) \quad$ (9)

The points are widely dispersed around the average line for the lowest oxygen concentrations.

Although the quality of the treated water decreased from one experimental period to the other, due to a reduction in the aeration time after the first period (see table 1), the initial equation (10) is only slightly modified if the 32 points from the second experience are considered (Eh* $=0.223+0.191 \log [02](n=64 ; r=0.91) \quad(10)$.

On the other hand, both the potentials and the dissolved oxygen concentrations at the end of the aeration cycle drop when the water quality drops.

At Colombes, the oxygen concentrations and potentials were stabilized at $5.6,2$ and $0.2 \mathrm{mg}$ $\mathrm{O}_{2} .1^{-1}$ for several hours. The regression equation obtained by plotting the corrresponding potentials against the logarithm of the dissolved oxygen concentrations for these values is :

$E h=0.180+0.148 \log \left[0_{2}\right] \quad(r=0.99 ; n=3)$ 
Figure 10 shows all the linear regressions obtained from potential and dissolved oxygen concentration measurements taken at Crisolles, Fontenay-Iresigny and Colombes (see figures 8 and 9 and equation 11). They also show the regression line representing the average of the two sets of measurements taken, in the laboratory, on Fontenay-Tresigny sludge aerated for 12 hours without feeding (see figure 5) : this line is the highest on figure 10 and its slope is $58 \mathrm{mV}$ per decade. The laboratory finding that adding substrate to sludge causes a drop in potential which is independent of the oxygen level is confirmed by the respective position of all these lines. The regression line obtained on Crisolles plant lies considerably below the previous one and has a steeper slope ( $91 \mathrm{mV}$ per decade). This indicates that the effect of the dissolved oxygen concentration on the overall redox situation in the medium is far higher than in the previous case.

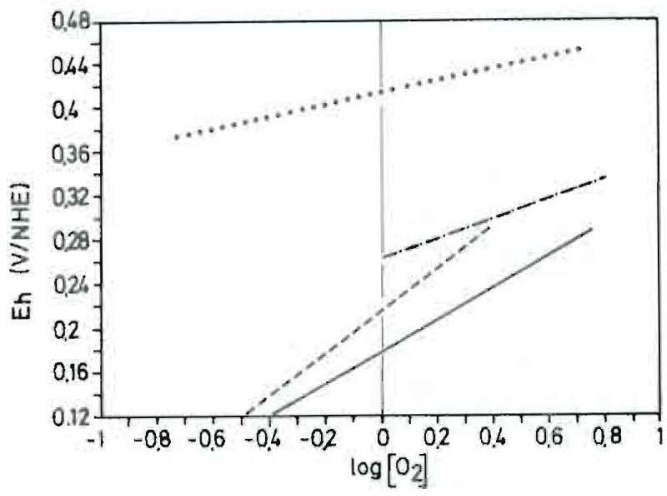

Fiq.10 : Comparison between the regression lines obtalned by plotting electrode potential in activated sludge versus $\log \left[\mathrm{O}_{2}\right]$ (...) laboratory samples from Fontenay-Tresigny when subjected to endogenic uptake rate. $(-,-$ ) in situ Crisolies site, $(-\cdots)$ in situ Fontenay-Tresigny site, (__ in situ Colombes site.

Like Crisolles plant, the Fontenay-Tresigny plant is very lightly loaded but the calculated regression ine is below that for Crisolles (the medium is more strongly reductive) and its slope is $197 \mathrm{mV}$ per decade (the dissolved oxygen concentration strongly affects the interstitial liquid redox situation). The position of this line, and its slope, can be explained by a probable evolution of the highly-concentrated sludge (see table 1) into strong anaerobic conditions in the settling tank and during the aerator shut-down periods (see figures 3 and 5 ); a second factor is the low dissolved oxygen concentrations pertaining at the end of the aeration periods. Finaliy, for the Colombes plant which operates at high sludge loading, the factor of proportionality between Eh and the logarithm of the dissolved oxygen concentration is high; at the same dissolved oxygen concentration, the potentials are always lower than those found in the other stations tested.

\section{CONCLUSIONS}

The electrochenical balance involving the dissolved oxygen plays a major role in establishing the equilibrium potential in activated sludge. The electrode potential at equilibrium ( $\mathrm{Eh}$ ) and the dissolved oxygen concentration $\left[\mathrm{O}_{2}\right.$ ] obey a law of the type Eh = a $+b \log \left[\mathrm{O}_{2}\right]$ (see figure 10). These experiments clearly show that the value of factors a and $b$ are considerably different from those calculated theoretically from the dissolved oxygen reduction reaction - see equation $1(0.8 \mathrm{~V} / \mathrm{EHN}$ and $15 \mathrm{mV} / \mathrm{dec}$ ade). This reaction does not, therefore, determine the equilibrium potential in activated sludge. Although the equilibrium potential and the dissolved oxygen concentration are closely linked, they are not "equivalent". The platinum electrode potential in activated sludge is affected by other electroactive species in the interstitial water whose nature and concentration are mainly determined by the load, the overall oxygen input, the aeration sequence and the sludge concentration. 


\section{REFERENCES}

Bejaoui, H. (1977). Application des mesures de potentiels d'oxydo-réduction à 1'exploitation des stations d'épuration par boues activées. Tech.Eau Assainissement, $366-367,19-33$.

Burbank, N. (1982). ORP - A tool for process control ? Appl. On-line Anal. Instrum. Process Control. Proc. Annu. Conf. Act. Sludqe Process Control, 1st. Meeting (Date 1981) ; Arthur, Robert M. ed., Ann Arbor Sci., Ann Arbor, Mich., 65-79.

Charpentier, J., Florentz, M., David, G. (1987). Oxidation reduction potential (ORP) regulation : A way to optimise pollution removal and energy savings in the low activated sludge process. Wat. Sci. Tech., 19, Rio, 645-655.

Coquery, M. (1986). Limites et applications des mesures de potentiels d'équilibre dans les boues activées. Mémoire de D.E.A. Sciences et Iechniques de l'Environnenent. Université paris Val de Marne - Agence Financière de Bassin Seine-Normandie CEMAGREE, $63 \mathrm{p}$.

Fujii, M. (1983)- Redox potential in control of activated sludge treatment of sewage of apartment development areas. Mizu Shori Gijutsu, 24 (9), 685-25.

Heduit, A., (1985) - Mesure de potentiels d'équilibre dans les boues activées. Mémoire de D.E.A. Sciences et Techniques de l'Environnement. Université de paris val de Marne - CEMAGREF, 25 P.

Heduit A., Leclerc L.A., Sintes L., Thevenot D.R., (1987.). Perspectives de maitrise des processus de nitrification et de cénitrification dans les boues activées à $\mathrm{I}^{\mathrm{r}} \mathrm{aide}$ du potentiel d'oxydo-réduction. Conférence IAuPRC/AIDE sur I'azote (Bruxelles) Accepted for publication in War.Sci.Techn.

Hedilt, A., Coquery M., Thevenot D.R., (1987b) - Potentiel droxydo-réduction en épuration biologique - méthode de mesure et applications. I.S.M. 05, 219,226.

Hitachi, Ltd. (1983). Process control in biological denitrification of wastewater. Patent Jpn. Kokaia Tokkyo Koho JP 58/196821 A2 (83/196891), 16 Nov. 1983, 5 pp.

Kankyo Engineering Co, Ltd. (1283). Activated sludge process control by redox potential Pattent Ipn. Kokai Tokkyo JP 58/202094 A2 (83/202094), 25 Nov. 1983, 6 PP

Meidensha Electric Mfg. Co, Ltd. (1980). Automatic control of wastewater treatment. Patent Jpn. Tokkyo Koho JP $55 / 23678(80 / 23678), 24$ jun. $1980,7 \mathrm{PP}$.

Milazzo C., (1269). Electrochimie. Dunod ed., Paris $426 \mathrm{pp}$.

Mitsubishi Heavy Industries, Ltd. (1984). Wastewater treatment. Patent Ipn. Kokai Tokkyo Koho JP $59 / 90695$ A2 $(84 / 90695), 25$ May 1984, 4 pP

Nippon Steel Corp. (1981). Activated sludge process control. Patent Jpr. Tokkyo Koho JP $56 / 27096(81 / 27096)$, 23 Jun $1981,6 \mathrm{pp}$.

Tanaka, K., Yasue, K. et coll. (1982) - Automatic control of biological denitrification process by use of redox potential. Mizu Shori Gijutsu, 23(8), 689-95. 